\title{
Vincent Tassenaar
}

\section{Over reusachtige Nederlanders}

De toename van de lichaamslengte in Nederland (18502007) in grote lijnen

In de twintigste eeuw werd de Nederlandse bevolking de langste bevolking (gemeten op het niveau van natiestaten) in de wereld. Aangezien de lengte van groepen een indicator is voor de (biologische) levensstandaard wordt dit verschijnsel gerelateerd aan de verbetering van de levensomstandigheden in Nederland. De vraag is in hoeverre deze ontwikkeling ook gepaard ging met een afname van ongelijkheid in levensstandaard. In dit artikel zullen de verschillen in lichaamslengte tussen sociale groepen en tussen de Nederlandse regio's worden besproken.

\section{Inleiding}

De vijfde landelijke groeistudie (2008-2009) leidde tot de constatering dat de lengtetoename van de Nederlandse mannen en vrouwen na anderhalve eeuw tot stilstand was gekomen. ${ }^{1}$ De resultaten in deze studie lijken aan te geven dat een opwaartse trend welke anderhalve eeuw had aangehouden is beëindigd. Niet alleen deze langdurige continue opwaartse swing is wellicht opvallend, maar evenzeer dat deze continue en sterke lichaamsgroei ertoe heeft geleid dat de Nederlandse mannen en vrouwen aan het einde van de twintigste eeuw de 'ranglijsten' van de langste wereldburgers mochten aanvoeren. ${ }^{2}$

Het contrast met het midden van de negentiende eeuw is in dit opzicht groot. In 1861 besloot de Nederlandse wetgever, de regering in samenwerking met het parlement, tot aanpassing van de militiewet. Voorafgaand aan deze wetswijziging vertoonde de lengteontwikkeling van de Nederlandse keurlingen een neerwaartse trend, het percentage jongemannen dat de 
minimumlengte (van 1,57 meter) niet wist te halen werd steeds groter. ${ }^{3}$ De Haarlemse arts Lucas Egeling, die onderzoek deed naar de antropometrische onderzoeksresultaten van de keuring der militieplichtigen in Noord-Holland te 1858 , verzuchtte in datzelfde jaar '(...) waar moet het henen als het steeds blijft voortgaan in diezelfde arithmetische reeks, die wij thans reeds over 40 jaren kunnen nagaan: altijd meerder, maar ook altijd kleiner!' ${ }^{4}$ Zoals de kinderarts Van Wieringen in zijn historische analyse van de Nederlandse lengtegroei in 1972 al vaststelde werd juist in deze jaren, qua lichaamslengte het dieptepunt bereikt en begon vervolgens de hierboven aangeduide opwaartse trend, welke in de literatuur als de seculaire groeiverschuiving wordt aangeduid. ${ }^{5}$

In dit artikel zal ik zowel ingaan op de afname in lichaamslengte in de negentiende eeuw als reflecteren op de toename in lichaamslengte die zich vanaf het midden van de negentiende eeuw manifesteerde. Lichaamslengte van groepen is een indicator waarmee de levensstandaard - een overigens nogal breed concept - kan worden geoperationaliseerd. De centrale vraag is of deze stijging en daling gepaard ging met toegenomen dan wel afgenomen ongelijkheid. In zoverre het de biologische levensstandaard in de eerste helft van de negentiende eeuw betreft, zal de lengte van bedelaars, die als representanten van de onderkant van de samenleving kunnen worden beschouwd - met de algemene ontwikkelingen (van 25-jarigen) worden vergeleken. Daarna zal - voor de hele onderzoeksperiode - een vergelijking van de biologische levensstandaard in de land- en kustprovincies worden gemaakt. Voordat ik op beide aspecten inga zal ik een nadere beschouwing geven op lengte als bron voor de levensstandaard.

\section{Lengte als indicator voor levensstandaard}

Sedert een aantal decennia wordt lichaamslengte door historici gebruikt om uitspraken te doen over het niveau van de levensstandaard in het verleden, een indicator die vooral bruikbaar is omdat het informatie verschaft over de levensstandaard van bevolkingsgroepen. ${ }^{6}$ De gemiddelde of mediane lengte van bevolkingsgroepen wordt gebruikt als een alternatieve indicator voor de materiële levensstandaard zoals het BBP per capita of het reëel inkomen. In individueel opzicht is lengte vooral een uitdrukking van het genetische pakket van een individu. Maar een gemiddelde lengte van een grote groep mensen is vooral een uitdrukking van omgevingsfactoren, zoals sociaaleconomische omstandigheden in de jeugd, omdat deze individuele genetische 
verschillen in een groep uitmiddelen. ${ }^{7}$ Ongunstige omgevingsfactoren zullen tot groeivertraging - geringere lengtetoename op jonge leeftijd - van groepen leiden. Indien deze ongunstige omgevingsfactoren langdurig aanhouden zal er uiteindelijk sprake zijn van een lagere finale lengte, waarbij moet worden aangetekend dat een lagere groeisnelheid tevens zal leiden tot een langere periode van groei. Dit laatste zorgt er voor dat leeftijds- en geslachtsspecifieke lengteverschillen - als gevolg van omgevingsfactoren - op jongere leeftijd groter zullen zijn dan op latere leeftijd.

Om een onderscheid te maken tussen de traditionele economische indicator voor levensstandaard, het BBP (of BNP) per capita, hanteren de meeste antropometrische historici het concept van de biologische levensstandaard. ${ }^{8}$ Lengte wordt beschouwd als indicator waarmee inzicht kan worden gekregen in de verhouding tussen enerzijds de voeding die een bevolking binnenkrijgt en anderzijds de mate waarin deze bevolking aan ziekte wordt blootgesteld (waardoor de lichaamsgroei wordt beperkt dan wel vertraagd) en de inspanningen die - in de vorm van arbeid - worden geleverd. ${ }^{9}$ Lengte is daarom de uitkomst van de netto geconsumeerde voeding en genetische aspecten, waarbij zoals eerder aangegeven voor groepen wordt verondersteld dat deze genetische verschillen binnen groepen tegenover elkaar wegvallen. ${ }^{10}$ Wat overblijft is derhalve de mate waarin een bevolking in haar biologische behoeftes voor instandhouding van het lichaam en groei kan voorzien.

Als multidimensionale indicator bevat de gemiddelde lengte (van groepen), anders dan conventionele maatstaven, informatie over verschillende aspecten van de levensstandaard en heeft deze daarom vanaf de jaren zeventig een opgang gemaakt binnen de economische en sociale wetenschap. De opkomst van lengte als indicator voor (de biologische) levensstandaard sloot dus aan bij de tendens in de jaren 1970 en 1980 om in plaats van de conventionele economische indicatoren zoals het BBP per capita en het reële loon gebruik te maken van quality of life-indices zoals de Human Development Index, waarin onder meer levensverwachting van de bevolking en de mate van het genoten onderwijs was verwerkt. ${ }^{11}$

Gedurende de hele periode waarin een persoon - in de lengte (!) groeit, hebben de hierboven genoemde omstandigheden invloed op de groei. Bij ongunstigere levensomstandigheden zal de lengtetoename van een beperktere omvang zijn. Dit zal deels, vooral als de omstandigheden tijdelijk - bijvoorbeeld door misoogsten, oorlogen, werkloosheid, epidemieën - minder gunstig zijn, in een later stadium worden gecompenseerd. Dit 
laatste wordt in de medische literatuur als catch-up growth aangeduid en is recentelijk door Eric Schneider ten behoeve van de historische antropometrie in een schema geplaatst. ${ }^{12}$ De effecten van groeivertraging zullen het grootst en een permanent karakter kunnen krijgen als iemand onder ongunstige omstandigheden leeft in de periode waarin een mens gemiddeld het meest groeit: in utero, gedurende het eerste jaar na de geboorte en gedurende de adolescentie. De eerste periode biedt daarbij nog het voordeel dat er een langere periode van catching-up is. Hierdoor zijn langetermijneffecten van een ongunstige periode gedurende de adolescentie veelal het sterkst. ${ }^{13}$

Waar het BBP per capita, zoals door Yves Seegers terecht opgemerkt, vooral gevoelig is voor scheve inkomensverdelingen en een kleine groep zeer welgestelden, is de lichaamslengte vooral een indicator die de levensstandaard van de lagere sociale strata en middengroepen meet. ${ }^{14}$ Daarnaast kunnen met behulp van antropometrisch materiaal wel uitspraken worden gedaan over de biologische levensstandaard van groepen die met traditionelere maatstaven, zoals het vrij lastig vaststelbare reëel inkomen worden gemist. ${ }^{15}$ Datzelfde geldt voor patronen in het voedselgebruik die hooguit op het niveau van provincies of gemeenten zijn te analyseren. ${ }^{16}$ In het laatste geval kan worden gedacht aan vrouwen, die in de formele economie, althans in de negentiendeeeuwse gangbare bronnen, veelal onzichtbaar zijn en 'bedelaars. ${ }^{17}$

Hoewel de antropometrische geschiedenis pas in de jaren 1980 zijn intrede in de Nederlandse geschiedschrijving deed, trok de ontwikkeling van de lichaamslengte der (mannelijke) Nederlanders al snel in het antropometrisch onderzoeksveld. ${ }^{18}$ De reden dat de historische lengteontwikkeling van de Nederlanders weldra internationale aandacht trok, lag in het feit dat de gemiddelde lengte van de Nederlanders een vrijwel ongeëvenaarde toename liet zien. Gemeten naar de lengte voor negentienjarigen nam de lengte van 161,87 (1851-1860) toe tot een gemiddelde lengte van 183,6 centimeter voor mannen van dezelfde leeftijd (2008-2009). ${ }^{19}$ Daarbij moet worden aangetekend dat in het midden van de negentiende eeuw de Nederlandse (jonge)mannen nog behoorlijk doorgroeide, zodat het uiteindelijke verschil in eindlengte wat lager ligt dan deze 21,5 centimeter verondersteld en op ongeveer 16-17 centimeter moet worden bepaald. ${ }^{20}$

Deze antropometrische transitie, waarbij de gemiddelde lengte door het plafond van voorafgaande periodes ging, wordt aangeduid met de term 'seculaire trend' of 'seculaire groeiverschuiving. ${ }^{21}$ Deze langdurige verandering behelst niet alleen een toename van lichaamslengte, maar ook een wijziging van het groeipatroon. In het eerste aspect schuilt het seculiere, 
terwijl achter het laatste de groeiverschuiving schuil gaat. Als gevolg van deze transitie kwamen jongens en meisjes eerder in de puberteit, zodat de bijbehorende groeispurt ook op jongere leeftijd plaatvond. Bij meisjes kwam daar nog bij dat de menarche, de eerste menstruatie, op jongere leeftijd plaatsvond. ${ }^{22}$ Hierdoor zijn jongens en meisjes ook eerder volgroeid, zodat doorgroei na het twintigste levensjaar, anders dan in de negentiende eeuw, heden ten dage in de meeste Westerse samenlevingen uitzonderlijk is.

De zwaksten der samenleving en de crisis van de vroege negentiende eeuw

Economische en economisch-historische handboeken leren ons dat conform de theorie van Simon Kuznets de ongelijkheid in een land toeneemt als gevolg van technologische ontwikkeling, waarna de daaruit voortvloeiende langdurige economische groei voor een afname van ongelijkheid zou zorgen. ${ }^{23}$ Deze, recent door Thomas Piketty bestreden theorie, zou het beste met behulp van de gemiddelde lengte, welke meer dan een BBP per capita gevoelig is voor ongelijkheid in samenlevingen, kunnen worden getest. De invloedrijke antropometrisch historicus John Komlos signaleerde in 1998 dat in de eerste helft van de negentiende eeuw de lichaamslengte in veel landen en regio's afnam, terwijl tegelijkertijd in deze staten het BBP per capita toenam. Komlos schreef dit fenomeen, aanvankelijk aangeduid als de early-modern growth paradox, maar al snel getypeerd als de Komlos-paradox, toe aan een aantal samenhangende aspecten, zoals commercialisering en als gevolg daarvan veranderende arbeidsverhoudingen, proletarisering (een groter deel van de bevolking werd in toenemende mate loonafhankelijk), urbanisatie, infrastructurele verbeteringen, demografische groei en gewijzigde ruilvoet tussen voedingsmiddelen en industriële producten. ${ }^{24}$

Nader onderzoek naar de gemiddelde lengte onder Nederlandse keurlingen heeft aangetoond dat deze door Komlos gesignaleerde tendens zich in de eerste helft van de negentiende eeuw ook in Nederland manifesteerde. Drukker en Tassenaar signaleerden voor de jaren 1820-1860 al in 1997 een afname van lichaamslengte die zich in alle regio's (zie hieronder) voortdeed. In mijn proefschrift ben ik specifiek ingegaan op de situatie in Drenthe. In deze regio namen de verschillen tussen de bevolkingsgroepen tussen 1820-1830 en de jaren 1850 toe. Vooral de biologische levensstandaard van arbeiders en een deel van de nijverheidslieden (wevers, kleermakers en schoenmakers) verslechterde in deze periode. ${ }^{25}$ 
Aangezien ook de levensomstandigheden in steden in deze periode minder goed werden is het de vraag wat er gebeurde met de zwaksten van de samenleving: de bedelaars. Op deze vraag kan met behulp van persoonsgegevens, waaronder lengtegegevens die zijn verzameld door de Maatschappij van Weldadigheid, een antwoord op worden gegeven. Tussen 1811 en 1886 waren bedelarij en landloperij delicten - juridisch gekwalificeerd als wanbedrijven - waarvoor opzending naar een bedelaarskolonie een mogelijke straf was. In toenemende mate werden bedelaars door de rechtbanken op grond van artikel 274 Code Penal en haar juridische opvolgers naast veelal een korte periode in hechtenis veroordeeld tot opzending naar een bedelaarskolonie. Hoewel in 1843 een dergelijke opzending bij Koninklijk Besluit aan gemeenten 'geadviseerd' werden in de daaropvolgende decennia vrijwel alle bedelaarskolonisten door een strafrechtelijk vonnis in een bedelaarskolonie geplaatst. Vanaf 1854 werd de rechter (ex artikel 271 Code Penal 1854) verplicht om in geval van recidivisme de veroordeelde naar een 'bedelaars- gesticht' te laten overbrengen. ${ }^{26}$ In de periode $1822-1866$ werden ... nieuwkomers geregistreerd, hetgeen als gevolg van recidivisme ongeveer 18.671 unieke personen oplevert.

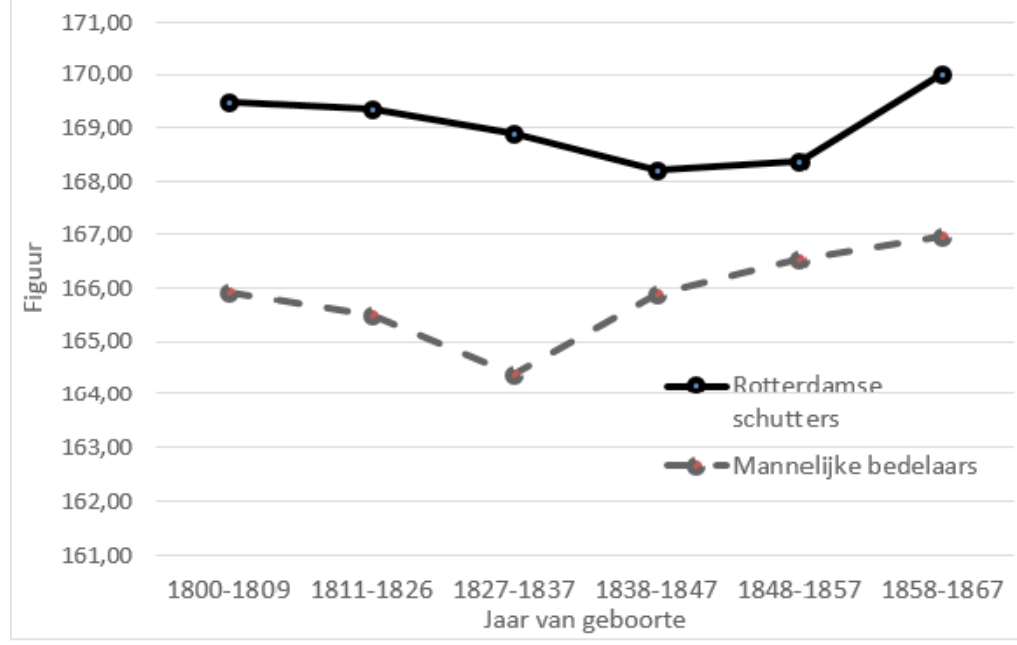

Figuur 1 Ontwikkeling van de gemiddelde lengte (eindlengte) van Rotterdamse schutters en bedelaars (Veenhuizen) 
Waarschijnlijk vanuit het oogpunt van identificatie werd bij inschrijving ook de lengte genoteerd, zodat waardevolle informatie over de levensomstandigheden van deze groep in hun kinder- jeugdjaren en jaren van vroege volwassenheid beschikbaar was. Vanaf 1841 gebeurde dit consequent op grond van het metrieke stelsel. Alleen de populatie veroordeelden die vanaf dat moment zijn gemeten is voor analyse bruikbaar. Daarnaast moet de onderzoekspopulatie worden beperkt tot de mannen en vrouwen tussen 25 en 50 jaar, omdat jongere personen nog in de groei zijn en na het vijftigste levensjaar de krimp een groot effect kan hebben. Met deze restricties blijft een populatie van 16.000 personen over die in de periode 1791-1837 werden geboren en informatie opleveren over verschillen tussen bepaalde bevolkingsgroepen en ontwikkeling daarvan in het eerste helft van de negentiende eeuw.

De gemiddelde lengte van de mannelijke bedelaars kan worden vergeleken met de gemiddelde lengte van andere mannen om vast te stellen wat de biologische levensstandaard van deze bedelaars was en hoe deze zich in het eerste deel van de negentiende eeuw ontwikkelde. Aangezien mannen in de negentiende eeuw tot hun 25ste doorgroeiden, heeft het weinig zin om de lengte van de mannelijke bedelaars te vergelijken met keurlingen die omstreeks hun 19de verjaardag werden gemeten. Een mogelijkheid bieden de schutterijregisters die vergelijkbaar zijn met de reguliere militieregisters met dien verschil dat dit instituut (de schutterij) pas in 1827 werd ingesteld en plaatsvond nadat mannen hun 25 ste levensjaar hadden bereikt. Van deze schutterijen zijn vooralsnog van slechts zeven plaatsen reeksen beschikbaar. In dit geval is de reeks van Rotterdam gebruikt omdat deze het meest overeenkomt, althans voor 19-jarigen met de nationale trend, de meeste waarnemingen in zich bergt en volledig is. In dit geval wordt het geboortejaar als uitgangspunt genomen.

De ontwikkeling van de lengte van de mannelijke bedelaars maakt twee zaken duidelijk. Ten eerste is de biologische levensstandaard van deze groep in de eerste vijfentwintig jaar van hun bestaan lager geweest dan bij andere bevolkingsgroepen - in dit geval gerepresenteerd door de Rotterdamse schutters - het geval was. Daarnaast is de tendens - in lijn met de ontwikkelingen van andere groepen - negatief; in die zin dat de gemiddelde lengte in eerste instantie sterker afneemt dan bij de Rotterdamse schutters het geval was. Deze afname hangt samen met de aardappelcrisis die vanaf 1845 grote gevolgen had voor de beschikbare voeding, een aantal epidemieën aan het einde van de jaren veertig en de duurtejaren tot het midden van de 
jaren vijftig. Het is logisch dat dit effect vooral optrad bij de cohorten uit de jaren 1827-1837, omdat deze groep hun adolescentiespurt omstreeks hun 18de levensjaar zal hebben gehad, ofwel in de jaren 1845-1855. Het maakt in ieder geval duidelijk dat deze kwetsbare groep gevoeliger was voor fluctuaties en voedselprijzen en derhalve het aanbod van voedsel.

De latere negentiende eeuw biedt nauwelijks een ander beeld dan de eerste helft van de eeuw, in dier voege dat het verschil in lengte tussen naar Veenhuizen gezonden bedelaars en Rotterdamse schutters gelijk blijft. In dit geval kunnen wij uit het onderzoek van Hans de Beer ook de lengte van 'gewone' gedetineerden betrekken. Het betreft hier mannen die in hechtenis waren genomen in het Huis van Bewaring, hetgeen betekent dat zij waren veroordeeld voor kleine vergrijpen, strafrechtelijk te kwalificeren als overtredingen, zoals ook economische delicten (zoals sluik, belastingontduiking, et cetera). Vanuit een sociaaleconomische oogpunt is dit een gemêleerdere groep dan de bedelaars, hetgeen ook bevestigd wordt door de gemiddelde lengte. Wat opvalt in figuur 2 is dat de gemiddelde lengte van Rotterdamse schutters, die als exemplarisch voor het algemene niveau in Nederland wordt beschouwd, veel eerder begint te stijgen dan die van de gedetineerden en bedelaars. Dat betekent dat de levensomstandigheden in Rotterdam, uitgaande van een groeispurt rond het $17 \mathrm{de}-18 \mathrm{de}$ levensjaar, in de latere jaren 1860 voor grote groepen begonnen te verbeteren, terwijl dat voor de andere groepen pas respectievelijk vijf dan wel tien jaar later het geval was. Bovendien lijkt er geen sprake van convergentie (het kleiner worden van de onderlinge verschillen), maar is zelfs omstreeks 1890 sprake van een groter verschil dan in het midden van de negentiende eeuw het geval was.

Het is interessant om de biologische levensstandaard van vrouwen, alhoewel in dit geval uitsluitend uit de laagste sociaaleconomische strata, te vergelijken met de levenstandaard van een qua sociaaleconomische positie vergelijkbare groep mannen. Binnen de antropometrische en historischdemografische literatuur worden discussies gevoerd over de positie van vrouwen en meisjes binnen het gezin. ${ }^{27}$ Naast de hierboven geschetste factoren als voeding, ziekte, en inspanning spelen aspecten als sociaalculturele normen en derhalve de rolverdeling en allocatie van middelen binnen een gezin een $\mathrm{rol}^{28}$ De achterliggende gedachte is daarbij veelal dat mannen een grotere claim op het aanwezige voedsel konden leggen, omdat zij meer buitenshuis actief waren en op die wijze duidelijker bijdroegen aan het gezinsinkomen. Vanuit dit gezichtspunt is verondersteld en in sommige gevallen aangetoond dat de positie van vrouwen in het verleden slechter was 
en er derhalve ook sprake was van een groter lengteverschil. ${ }^{29}$ Daarnaast veronderstelt deze stellingname dat vooral vrouwen te lijden zullen hebben gehad van verslechteringen van de voedselsituatie en profiteerden van verbeteringen in de biologische levensstandaard.

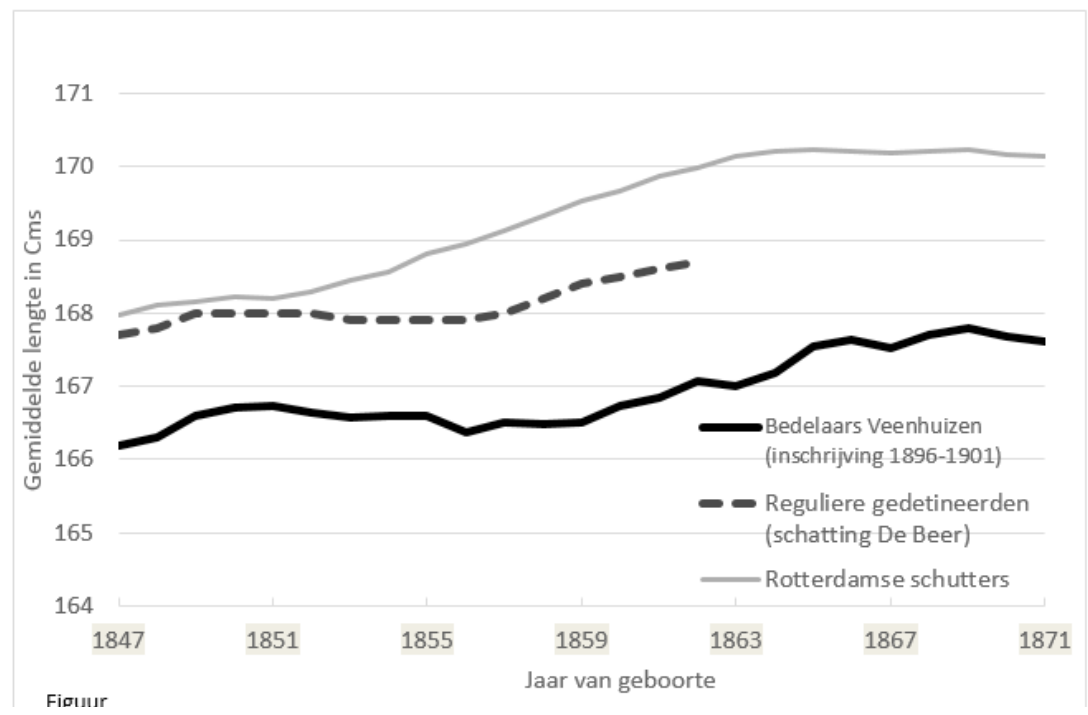

Figuur 2 Ontwikkeling van de gemiddelde lengte (eindlengte) van Rotterdamse schutter, gevangenen (De Beer sample) en bedelaars (Veenhuizen) [9-jaarlijks voortschrijdend gemiddelde]

De lengtegegevens van de vrouwelijke bedelaars die in de periode 18411866 werden ingeschreven in Veenhuizen lijken niet te wijzen op stelselmatige achterstelling binnen het gezin ten opzichte van hun broers, zodat derhalve geen sprake lijkt te zijn geweest van een relatief lagere biologische levensstandaard. Naar een hedendaagse standaard is het lengteverschil gering en dit is ook het geval als het wordt afgezet tegen de hedendaagse variatie. Daarmee bevestigen deze gegevens de conclusies van De Beer, die evenmin een aanwijzing vond voor een gender-bias. ${ }^{30} \mathrm{Dit}$ wordt duidelijk als gekeken de impact van de hongerjaren wordt bestudeerd. In deze periode nam het verschil tussen mannen en vrouwen - zoals gevisualiseerd in figuur 3 - niet ten nadele van vrouwen toe, terwijl naderhand ook geen extra toename van de gemiddelde lengte van vrouwen kon worden waargenomen. 


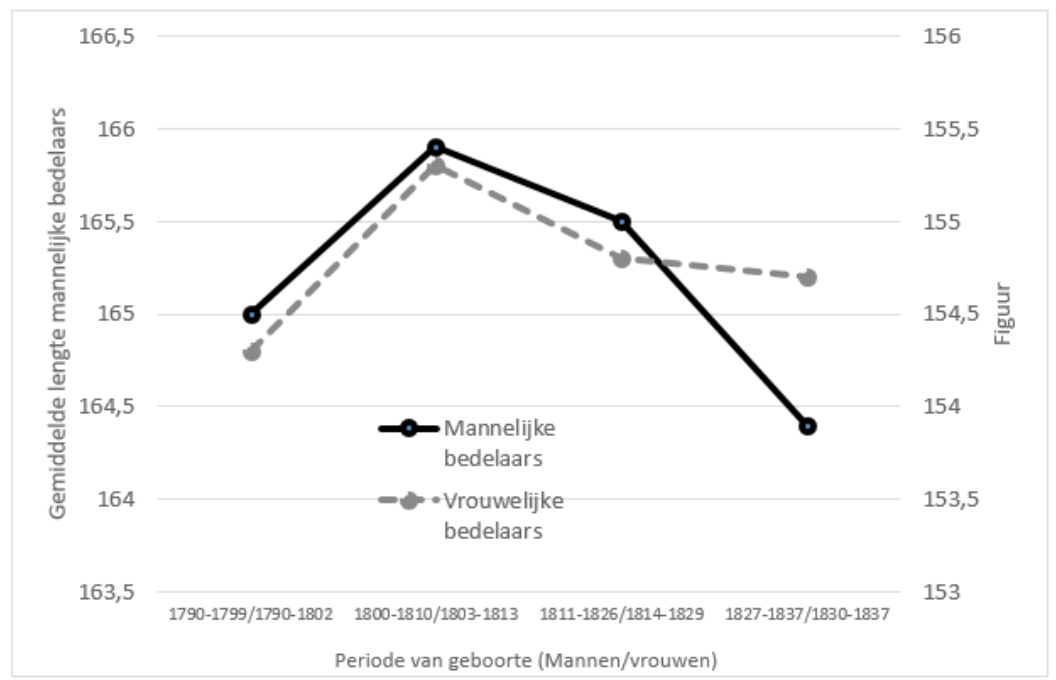

Figuur 3 Ontwikkeling van de gemiddelde lengte (eindlengte)van mannelijke en vrouwelijk bedelaars (opgenomen 1841-1866)

\section{Kustbewoners naar grote hoogte, variatie in lengteontwikkeling in Nederland}

Tot het derde kwart van de negentiende eeuw woonden de langste Nederlanders in het oosten en het zuiden van het land. De inwoners van deze provincies, die in de literatuur veelal worden aangeduid als de landprovincies, profiteerden van de ruimere hoeveelheid aan voedsel die - waarschijnlijk als gevolg van afnemende voedselkwaliteit bij bewaring en transport - ook nog van een betere kwaliteit was. Anders dan in de kustprovincies en in het bijzonder de urbane centra daarbinnen het geval was, werd in de landprovincies een groter deel van het voedsel lokaal geconsumeerd. Het hierboven geschetste fenomeen deed zich niet alleen voor in Nederland, maar is in deze periode in vrijwel alle regio's in Europa en daarbuiten zichtbaar. ${ }^{31}$ Behalve dat dit verschil diverse keren voor (Nederlandse) keurlingen is beschreven, is dit verschil ook zichtbaar in de populatie vrouwelijke bedelaars. Opvallend daarbij is dat in de vroege negentiende eeuw het verschil tussen vrouwelijk bedelaars geboren in kust en landprovincies statistisch significant is, maar ook beduidend kleiner was dan bij mannelijke bedelaars en schutters het geval was. Vrouwen uit de kustprovincies waren gemiddeld 155,6 centimeter 
lang, terwijl hun seksegenoten in het binnenland een gemiddelde lengte van 156,6 centimeter bereikten.

In de late negentiende eeuw kantelde het ruimtelijke patroon, hetgeen door infrastructurele en technische veranderingen kan worden verklaard. Verbeteringen in het infrastructurele netwerk, koel- en conserveertechnieken maakten zowel de bevoorrading (in assortiment) en de kwaliteit van de aangeleverde producten beter. Meer dan de inwoners van de landprovincies profiteerden de inwoners van de kustprovincies van het verdwijnen van de urban penalty. Deze urban penalty is een in de literatuur omschreven fenomeen dat inhoud dat het leven in de stad in verschillende opzichten minder gezond was dan het leven op het platteland. In de middelgrote steden was vanaf het laatste decennium van de negentiende eeuw sprake van een urban premium, hetgeen betekent dat levensomstandigheden daar gunstig waren (geworden) dan op het platteland. ${ }^{32}$

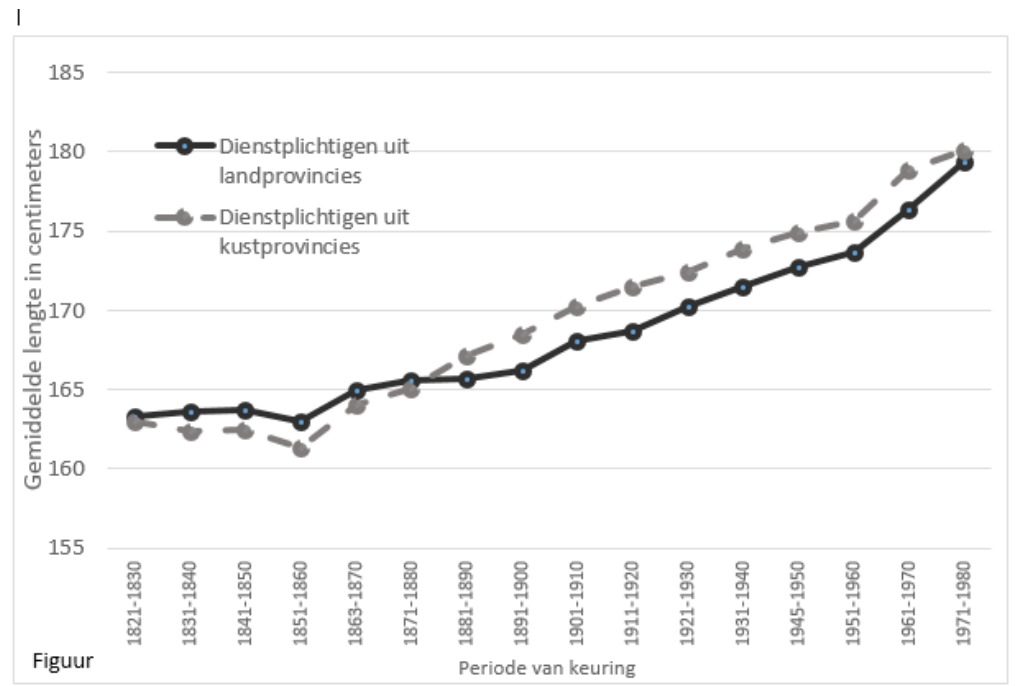

Figuur 4 Regionale ontwikkeling van de gemiddelde lichaamslengte van gekeurde dienstplichtigen (19 jaar)

Terwijl er in de middelgrote steden vanaf het einde van de negentiende eeuw sprake was van een urban premium bleven de inwoners van de grootste steden, zoals in Nederland, Amsterdam, Rotterdam en 's Gravenhage, in lengte achter. Opvallend genoeg, bleek dit patroon - bevestigd door de gegevens uit de HSN-databases - in de gehele twintigste eeuw persistent. In de 
eerste helft van de twintigste eeuw, waarin de lengte ondanks de economische problemen bleef toenemen (zie figuur 4) convergeerde de gemiddelde lengte van Amsterdamse keurlingen met die uit Noord-Brabant en Drenthe, terwijl de keurlingen uit de rest van Noord-Holland de lucht letterlijk en figuurlijk in schoten. De biologische levensstandaard in Amsterdam was per saldo dus gelijk aan die in de landprovincies, alhoewel de verklaring voor dit niveau waarschijnlijk anders zal zijn. De laatste groeistudies uit 1997 en 2007 geven aan dat de lengte in de grote steden, zelfs gecorrigeerd voor opleiding en inkomen, nog steeds iets lager is dan de rest van het kustgebied. ${ }^{33}$ Wel blijkt uit de laatste groeistudie dat er in de vroege eenentwintigste eeuw sprake is van regionale convergentie.

\section{Conclusie}

Een één-op-één relatie tussen een afname van ongelijkheid en een toename van de lichaamslengte kan slechts met de nodige voorzichtigheid worden aanvaard. Voor de meest zwakke groepen uit de samenleving blijkt deze in de negentiende eeuw niet zo eenvoudig vast te stellen. Sommige bevolkingsgroepen konden, qua toename van de lichaamslengte, de nationale trend niet volgen. Voor de twintigste eeuw zijn er nog geen studies en/of data beschikbaar die een langetermijnontwikkeling kunnen bieden waarmee convergerende of divergerende ontwikkelingen kunnen worden aangetoond. De laatste studies laten zien dat hoger opgeleide jongeren significant langer zijn dan hun leeftijdsgenoten met lagere opleiding. Vergelijkbare verschillen zijn zichtbaar als de sociaaleconomische positie van het gezin van de gemetenen als uitgangspunt wordt genomen. Derhalve, hoewel de verschillen in de twintigste eeuw zijn afgenomen, zijn sociaaleconomische verschillen nog steeds fysiek zichtbaar.

Op regionaal niveau, althans met het oog op het verschil tussen de kust en landprovincies, was tot aan het midden van de twintigste eeuw sprake van een divergerende tendens in het nadeel van de landprovincies. In het vervolg van de twintigste eeuw bleef dit verschil bestaan, totdat in de laatste decennia sprake lijkt te zijn van een convergerende tendens. In het grootste deel van de twintigste eeuw bleef desondanks een duidelijk verschil bestaan tussen de mannen uit de kustprovincies en landprovincies. De kustbewoners, waaronder de Groningers, staken een paar centimeter boven hun leeftijdsgenoten uit de oostelijke en zuidelijke delen van Nederland uit. Verklaringen voor de regionale als sociaaleconomische verschillen 
zullen in de samenstelling van het dagelijks menu, blootstelling aan ziekte, inspanningen, sport en lifestyle worden gezocht.

\section{Noten}

De kwantitatieve gegevens uit dit artikel hadden nimmer gepresenteerd kunnen worden zonder het vlijtige werk van twee research-assistenten: Marlies Zaadnoordijk (2018-2019) en Sietske Wiersma (2019-2020). De informatie uit de signalementskaarten zijn in 1996 verzameld door Menze Poortman in het kader van een doctoraal kernvakcollege. Mijn dank aan hen is groot. Ik dank daarnaast de leden van de redactie voor hun opmerkingen bij eerdere versies van dit artikel.

1. Y. Schönbeck, H. Talma, P. van Dommelen, B. Bakker, S.E. Buitendijk, R. A. Hirasing en S. van Buuren, 'The world's tallest nation has stopped growing taller: the height of Dutch children from 1955-2009,' Pediatric research, 73 (3) (2013), 371-377.

2. De Nederlanders zijn nog steeds het langste volk, NOS Journaal, NPO vrijdag 23 augustus 2019 (20.00 uur), fragment. https://www.npostart.nl/nosjournaal/23-08-2019/POW_04059489.

3. De Nederlandse regering besloot derhalve om de vereiste minimumlengte terug te brengen tot 1,55 $\mathrm{m}$ en de leeftijd waarop de mannen werden gekeurd een jaar te verlaten. Aanvankelijk betrof het regeringsvoorstel een reductie tot 1,56, maar uiteindelijk werd de minimumlengte teruggebracht tot $1,55 \mathrm{~m}$.

4. L.J. Egeling, 'Verslag namens de Commissie voor statistiek, der Nederlandsche Maatschappij tot bevordering der geneeskunst. Voorgedragen op de algemeene vergadering te Rotterdam der 23sten Junij 1858,' Nederlands Tijdschrift voor Geneeskunde (1858), 483.

5. J.C. van Wieringen, Seculaire groeiverschuiving. Lengte en gewicht surveys 19441966 in Nederland in Historisch perspectief. Samenvatting in het Engels, tabellen en figuren, (Leiden: TNO 1972), 6-7.

6. R.J. Steckel, 'Stature and the standard of living,' Journal of economic literature 33 (1995), 1908.

7. Steckel, 'Stature and the standard of living,' JEL 1903.

8. Komlos, V. Tassenaar, 'Development of regional variety of the biological standard of living in the Netherlands, 1812-1913,' Economics and Human Biology, 34 (2019) 151.

9. Steckel, 'Stature and the standard of living,' JEL 1905. 'Tassenaar, Development of regional variety,' $E H B, 151-152$.

10. J. Komlos, 'Anthropometric history: an overview of a quarter century of research, Anthropologischer Anzeiger, 68 (2009) 342-343. Steckel, 'Stature and the standard of living,' JEH, 1903.

11. Komlos, 'Anthropometric history', Anthropologischer Anzeiger, 341-342.

12. E. Schneider, 'Children's growth in an adaptive framework: explaining the growth 


\section{Tassenaar}

patterns of American slaves and other historical populations,' Economic History Review (2016), 3.

13. J.P.A.M. Jacobs en V. Tassenaar, 'Height, income and nutrition in the Netherlands in the second half of the 19th century', Economics and Human Biology 2 (2004), 181195.

14. Y. Segers, Economische groei en levensstandaard. De ontwikkeling van de particuliere consumptie en het voedselgebruik in Belgie, 1800-1913 (2003).

15. R.H. Steckel en A. Kjellström, 'Measuring community health using skeletal remains,' In: R.H. Steckel e.a. (red.) The backbone of Europe. Health, diet, work and violence over two millennia, (2019), 52-53.

16. Een zeer geslaagde poging is ondernomen door Richard Paping voor het Groninger kleigebied. Dit onderzoek- is mede door de aanwezigheid van unieke en rijke data- niet eenvoudig reproduceerbaar voor andere regio's. In zijn dissertatie gaat ook kritisch in op de beperkingen die aan het concept reëel inkomen kleven, terwijl hij ook een uiteenzetting geeft over de haken en ogen bij de vaststelling van (de hoogte van) deze indicator. R.F.J. Paping, Voor een handvol stuivers, (1995). Gegevens over consumptie zijn veelal af te leiden via productiegegevens dan wel belastinggegevens, hoewel de laatste gegevens wat beperkt worden door smokkel of sluik.

17. Nicola Koepke, Joel Floris, Christian Pfister, Frank Rühli, Kaspar Staub, 'Ladies first: Female and male adult height in Switzerland, 1770-1930', Economics and Human Biology, 29 (2018) 77. https://doi.org/10.1016/j.ehb.2018.02.002.

18. J.J. de Meere, Economische ontwikkeling en levensstandaard in Nederland, ('s Gravenhage 1982). H.J. Brinkman, J.W. Drukker en B. Slot, 'Lichaamslengte en reëel inkomen: een nieuwe schattingsmethode voor historische inkomensreeksen' Economisch- en sociaal-historisch jaarboek 51 (1988) 35-79. Brinkman cum suis, stellen in deze publicatie dat lengte als equivalent van het BNP per capita kan worden beschouwd. Zij gingen daarbij nog een stap verder en probeerden op basis van de mediane lengte deze (economische) maatstaf te schatten. Deze methode heeft naderhand nauwelijks navolging gekregen. Vincent Tassenaar, Het verloren Arcadia. De biologische levensstandaard in Drenthe, 1815-1860. (Capelle a.d. Ijssel: Labyrint publication, 2000) 289. Steckel, 'Stature and standard of living.' JEL 1920.

19. 1851-1860: Tassenaar, Het verloren Arcadia, 289. 2008-2009: Schönbeck e.a., 'The world's tallest nation,' 372 .

20. Dit verschil (167,1 voor de geboortecohort 1831-1840, gekeurd op grond van Wet op de schutterijen 1827 in de jaren 1856-1865) is gebaseerd op de gegevens van 25 -jarigen uit de studie van Oppers. Omdat Oppers uitsluitend gebruikt heeft gemaakt van keurlingen uit steden is er waarschijnlijk sprake van een te laag gemiddelde. De hedendaagse gegevens komen uit: Schönbeck et al., 'The world's tallest nation, Pediatric Research, 372.

21. Van Wieringen, Secualire groeiverschuiving, 6-7. Koepke et al., 'Ladies first', EHB, 80-81.

22. T.B. Cage, 'The evolution of human phenotypic plasticity: Age and nutritional status at maturity, Human Biology 75 (2003), 530.

23. J.W. Drukker, De revolutie die in haar eigen staart beet. (Utrecht: Lemma, 2003) 189-

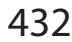




\section{Over reusachtige Nederlanders}

190. M. Mackintosh e.a., Economics and changing economics (Londen: The Open University 1996), 181-182.

24. J. Komlos, 'Shrinking,' JEH, 785-789.

25. Tassenaar, Het verloren Arcadia, 221-223 en 242.

26. Jacob Bierens de Haan, De Nederlandsche strafbepalingen tegen bedelarij en landlooperij: een historisch, statistisch en kritisch onderzoek, (Utrecht 1895), 90-91

27. I. Devos, 'Te jong om te sterven: de levenskansen van meisjes omstreeks 1900,' TSEG, 26 (2000), 70-71.

28. Koepke, et al., 'Ladies first', $E H B, 84$.

29. S. Horrell en D. Oxley, 'Gender bias in nineteenth-century England: evidence from factory children', Economics and Human Biology, 22 (2016), 58.

30. H. de Beer, 'Physical stature and biological living standards of girls and young women in the Netherlands, born between 1815 and 1865, History of the Family 15 (2010), 71.

31. R. Floud, K. Wachter, A. Gregory, Height, health and History. Nutritional Status in the United Kingdom, 1750-1980, (Cambridge 1990), 204; L. Heyberger, 'Received wisdom versus reality: height, nutrition, and urbanization in mid-nineteenth-century France,' Cliometrica 8 (2014), 128-130; J. Komlos en J., Baten, 'Looking Backward and Looking Forward: Anthropometric Research and the Development of Social Science History', Social Science History 28 (2004), 191-210; R.R. Munoz, Biological standards of living in rural Catalonia over the long run: A comparison with urban areas (1840-1960), Nutricion hospitalaria: organa ofical de la Sociedad Espagnola de Nutriction parental Y enternal, (2018), 59; E. De Pauw, 'Tall Farmers and Tiny Weavers. Rural Living Standards and Heights in Flanders, 1830-1870, TSEG. The Low Countries Journal of Social and Economic History 14 (2017), 82; Tassenaar, Het Verloren Arcadia, 30-32.

32. Tassenaar, 'Development of regional variety', EHB, 158.

33. Schönbeck et al. 'The world's tallest nation,' Pediatric Research, 372. 